\begin{tabular}{|l|l|l||}
\hline \multicolumn{2}{|c|}{ PublisherInfo } \\
\hline \hline PublisherName & $:$ & BioMed Central \\
\hline \hline PublisherLocation & $:$ & London \\
\hline \hline PublisherImprintName & $:$ & BioMed Central \\
\hline \hline
\end{tabular}

\title{
IL-5 induces leukotriene receptor expression
}

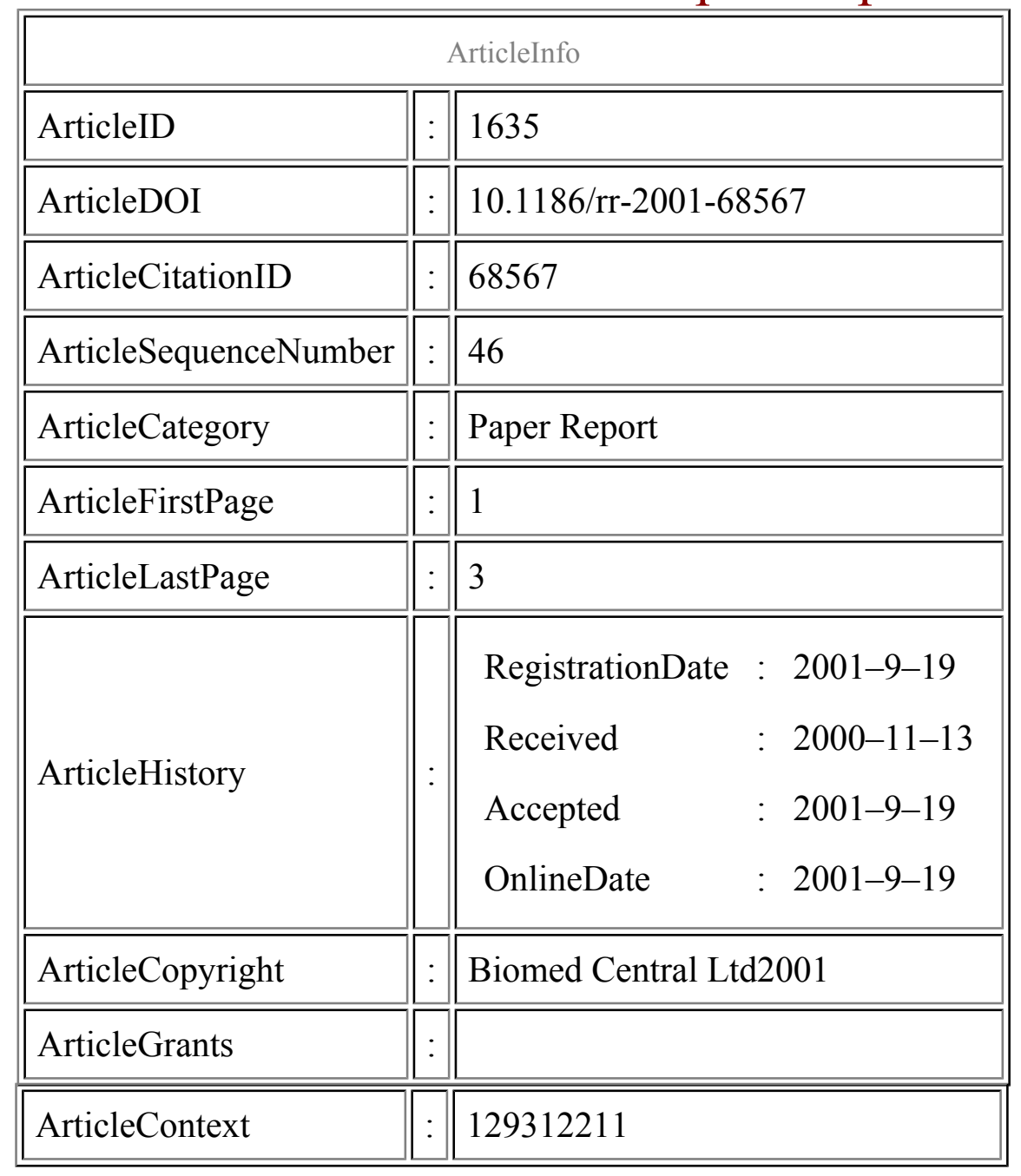


Andrea Heinzmann, Aff1

Corresponding Affiliation: Aff1

Aff1 Wellcome Trust Centre for Human Genetics, Oxford, UK

\section{Keywords}

Asthma, eosinophils, IL-5, LT D4 receptor

\section{Context}

Leukotrienes are important mediators in the pathogenesis of acute bronchoconstriction, chronic airway inflammation and persistent eosinophilia in the airways and blood of asthmatics. The main source of leukotrienes in the asthmatic lung is the eosinophil. Recently the receptor for leukotriene (LT) $\mathrm{D}_{4}\left(\mathrm{CysLT}_{1} \mathrm{R}\right)$ was characterized and its expression on HL-60/eos cells was shown. Interleukin (IL)-5 is an important regulator of many eosinophil functions including chemotaxis, degranulation, and adhesion. This study used the model of HL-60/eos cells to determine the influence of IL-5 on the expression and function of $\mathrm{CysLT}_{1} \mathrm{R}$ in eosinophils.

\section{Significant findings}

IL-5 induced a concentration- and time-dependent augmentation of CysLT $\mathrm{T}_{1} \mathrm{R}$ mRNA expression in HL-60/eos cells. The accumulation of CysLT 1 R mRNA was abrogated by pretreatment of the cells with actinomycin D (an inhibitor of RNA synthesis), suggesting an enhancement of transcription as the underlying mechanism. Furthermore, IL-5-induced transcription of CysLT ${ }_{1} \mathrm{R}$ mRNA was associated with an increased expression of CysLT $T_{1}$ R protein on the cell surface of HL-60/eos cells. The upregulation of $\mathrm{CysLT}_{1} \mathrm{R}$ expression led to an elevated calcium flux in response to LT $\mathrm{D}_{4}$ and an enhanced chemotactic response of HL-60/eos to LT $\mathrm{D}_{4}$ - thus demonstrating the functional importance of the IL-5 induced $\mathrm{CysLT}_{1} \mathrm{R}$ expression.

\section{Comments}


This paper presents a new pathophysiologic mechanism by which IL-5 exerts its role on eosinophils and provides further insight into the involvement of IL-5 in the pathogenesis of asthma and allergic diseases. IL-5 modulates the expression of CysLT ${ }_{1} \mathrm{R}$ and thus determines the response of eosinophils to LT D4, a potent stimulator of the inflammatory response. As shown in previous studies, IL-5 activates several other proteins involved in eosinophil growth and differentiation. The possible complex interaction of these proteins with the observed upregulation of CysL T 1 R by IL-5 requires further investigation. The knowledge of the exact pathway by which leukotrienes and their receptors are involved in the regulation of the immune response is especially important to enable the responsible use of leukotriene receptor antagonists in the treatment of asthma.

\section{Methods}

HL-60 cells, RT-PCR, northern blot, flow cytometry, $\mathrm{Ca}^{2+}$ mobilization assay, chemotaxis assay

\section{Additional information}

\section{References}

1. Thivierge M, Doty M, Johnson J, Stankova J, Rola-Pleszczynski M: IL-5 upregulates cysteinyl leukotriene 1 receptor expression in HL-60 cells differentiated into eosinophils. J Immunol. 2000, 165: 5221-5226.

This PDF file was created after publication. 